\title{
Analisis Kemampuan Representasi Matematis Siswa SMK Ditinjau dari Gaya Belajar
}

\author{
Elsa Komala*, Asri Maulani Afrida \\ Pendidikan Matematika, Universitas Suryakancana, Indonesia \\ *elsakomala@gmail.com
}

\begin{tabular}{|c|c|}
\hline Article Info & Abstract \\
\hline $\begin{array}{l}\text { Received } \\
01 \text { October } 2020\end{array}$ & $\begin{array}{l}\text { This research aims to describe the mathematical representation } \\
\text { abilities of vocational school students in terms of visual, auditory, and } \\
\text { kinesthetic learning styles, as well as learning styles that have the best } \\
\text { representational abilities in mathematics learning. The research was }\end{array}$ \\
\hline $\begin{array}{l}\text { Revised } \\
27 \text { October } 2020\end{array}$ & $\begin{array}{l}\text { conducted at SMK Negeri } 2 \text { Cilaku Cianjur. The research method used } \\
\text { is descriptive research with a quantitative approach. The subjects in } \\
\text { this study were all } 29 \text { students of class X TKJ } 2 \text { with purposive }\end{array}$ \\
\hline $\begin{array}{l}\text { Accepted } \\
11 \text { November } 2020\end{array}$ & $\begin{array}{l}\text { sampling technique. The data used are written tests to reveal } \\
\text { mathematical representation abilities, observation and questionnaires } \\
\text { to classify students based on learning styles, interviews with students. }\end{array}$ \\
\hline Keywords & $\begin{array}{l}\text { Data processing used descriptive analysis of the percentage of posttest } \\
\text { scores, learning styles by looking at the percentage of observation } \\
\text { statements and answers to student questionnaire statements. The }\end{array}$ \\
\hline Mathematical & results of the data analysis showed that the percentage of achievement \\
\hline Representation & of the mathematical representation ability of students with a visual \\
\hline Ability, & learning style was $71.43 \%$ in the sufficient category, students with the \\
\hline Learning Style & $\begin{array}{l}\text { auditory learning style } 71.25 \% \text { in the sufficient category, and students } \\
\text { with the kinesthetic learning style } 73.89 \% \text { with the sufficient category. } \\
\text { The kinesthetic learning style has the best representation ability in } \\
\text { mathematics learning with a percentage of } 73.89 \% \text { with a sufficient } \\
\text { category. }\end{array}$ \\
\hline
\end{tabular}

How to Cite:

Komala, E., \& Afrida, A. M. (2020). Analisis Kemampuan Representasi Matematis Siswa SMK Ditinjau dari Gaya Belajar. Journal of Instructional Mathematics, 1(2), 53-59.

\section{PENDAHULUAN}

Matematika memiliki peranan yang sangat penting dalam berbagai aspek kehidupan manusia. Banyak permasalahan yang terjadi serta kegiatan dalam kehidupan sehari-hari dapat diselesaikan dengan menggunakan matematika. Sehingga matematika dipandang ilmu yang penting untuk dikuasai siswa, dan sebagai bekal yang dapat membantu menyelesaikan permasalahan yang dihadapi siswa dalam kehidupan. Hal ini disebabkan karena matematika merupakan salah satu bidang ilmu yang dapat meningkatkan kemampuan seseorang dalam berpikir dan melakukan kemampuan matematika yang baik.

Menurut NCTM (2000: 29) dinyatakan terdapat lima standar yang yang perlu dimiliki siswa berupa pemahaman, pengetahuan dan keterampilan dalam standar proses yang meliputi: pemecahan masalah, penalaran dan pembuktian, komunikasi, koneksi dan representasi. Sejalan dengan Sabirin (2014: 33) yang menyatkan bahwa representasi merupakan model atau bentuk pengganti dari suatu situasi masalah yang digunakan untuk menemukan solusi. Cai, Lane, \& Jakabcsin (1996) mengungkapkan representasi merupakan cara yang digunakan seseorang 
untuk mengkomunikasikan jawaban atau gagasan matematika yang bersangkutan. Representasi yang dimunculkan oleh siswa merupakan ungkapan dari gagasangagasan atau ide-ide matematis yang ditampilkan siswa dalam upaya mencari solusi dari masalah yang sedang dihadapinya sebagai hasil dari interpretasi pikirannya (NCTM, 2000: 67).

Pentingnya kemampuan representasi matematis menurut NCTM (2000: 67) mengharuskan siswa untuk: (1) menciptakan dan menggunakan representasi untuk mengorganisir, mencatat, dan mengkomunikasikan ide-ide matematis, (2) memilih, menerapkan, dan menerjemahkan representasi matematis untuk memecahkan masalah, (3) menggunakan representasi untuk memodelkan dan menginterpretasikan fenomena fisik, sosial, dan fenomena matematis. Dengan demikian, kemampuan representasi matematis diperlukan siswa untuk menemukan dan membuat suatu alat atau cara berpikir dalam mengkomunikasikan gagasan matematis dari yang sifatnya abstrak menuju konkret, sehingga lebih mudah untuk dipahami.

Namun fakta di lapangan berdasarkan hasil wawancara yang dilakukan kepada seorang guru matematika kelas $\mathrm{X}$ di salah satu SMK Negeri di Cianjur diketahui bahwa kemampuan representasi matematis siswa masih belum optimal. Belum optimalnya kemampuan representasi matematis siswa juga dapat dilihat dari nilai hasil ulangan semester, dalam satu kelas siswa yang mendapat skor maksimal saat ulangan semester terutama yang berkaitan dengan merepresentasikan soal hanya sekitar 35\% siswa yang mampu menjawab dengan benar. Sekitar $65 \%$ siswa masih belum bisa menyampaikan dan menghubungkan ide-ide matematis yang mereka punya dengan ide-ide matematis yang dapat ditemukan pada permasalahan. Sejalan dengan Komala, Suryadi \& Dasari (2020), terkait dengan kemampuan siswa dalam merepresentasikan visual, merepresentasikan dalam bentuk pemodelan matematika dan merepresentasikan dalam bentuk kata-kata siswa masih mengalami hambatan, misalnya kurangnya variasi soal sehingga harus memberikan soal-soal yang melatih kemampuan anak dalam merepresentasikan konsep-konsep yang ada bentuk visual, simbol dan notasi matematika, dan kata-kata, mengurangi pemberian soal-soal yang sejenis, lebih menambahkan soal-soal yang lebih aplikatif dan mengaitkan konsep trigonometri. Dengan adanya variasi soal tersebut kemungkinan dapat mengakomodir gaya belajar yang ada pada siswa.

Nurhayati \& Subekti (2017: 57) menyatakan bahwa salah satu faktor yang dapat mempengaruhi kemampuan representasi matematis siswa adalah gaya belajar. Gaya belajar yang dimaksud disini mengacu pada teori De Poter \& Hernacki (2015: 115) yang mengatakan bahwa modalitas dalam belajar ada 3 kelompok yaitu: gaya belajar visual yakni mengakses citra visual yang diciptakan maupun mengingat, gaya belajar auditori yakni mengakses jenis musik dan katakata, serta gaya belajar kinestetik yakni menerima gerak dan emosi.

Smith (dalam Gallenstein, 2005: 28) mengatakan bahwa aplikasi dari representasi menurut Bruner dalam pembelajaran matematika adalah secara fisik melakukan aktivitas matematika menggunakan manipulatif, melakukan aktivitas mental matematika dengan berpikir berkenaan dengan ingatan petunjuk visual, auditori atau kinestetik, dan pada akhirnya mampu menggunakan simbol angka dengan maknanya. Hal ini menyiratkan bahwa saat siswa ingin menunjukkan kemampuan representasi matematisnya untuk menyelesaikan masalah 
matematika, maka siswa berusaha mengingat kembali pengetahuan yang mereka dapat sebelumnya sehingga mendapatkan petunjuk untuk menyelesaikan masalah. Petunjuk yang siswa dapat merupakan suatu aktivitas berpikir matematika baik secara visual, auditori atau kinestetik berdasarkan pengetahuan yang mereka dapatkan sebelumnya.

Fokus penelitian ini adalah untu mendeskripsikan bagaimana kemampuan representasi matematis siswa yang memiliki gaya belajar visual, gaya belajar auditorial dan gaya belajar kinestetik; serta untuk melihat gaya belajar apa yang memiliki kemampuan representasi paling baik dalam pembelajaran matematika.

\section{METODE PENELITIAN}

Metode yang digunakan yaitu metode deskriptif dengan pendekatan kuantitatif. Subjek dalam penelitian ini adalah siswa kelas X TKJ 2 SMK Negeri 2 Cilaku Cianjur sebanyak 29 orang siswa. Instrumen yang digunakan berupa tes kemampuan representasi matematis pada materi trigonometri, observasi dan angket gaya belajar siswa, dan wawancara kepada 9 orang siswa yang dipilih berdasarkan kategori gaya belajar.

Tes kemampuan representasi matematis terdiri dari 5 soal, 2 soal untuk kemampuan representasi visual, 2 soal untuk kemampuan representasi persamaan atau ekspresi matematis, dan 1 soal untuk kemampuan representasi kata-kata atau teks tertulis.

Observasi dilakukan untuk mengetahui gaya belajar siswa dalam mengikuti pembelajaran matematika. Lembar observasi berupa daftar cek sebagai acuan pelaksanaan observasi yang dikembangkan berdasarkan teori indikator gaya belajar.

Angket bertujuan untuk mengelompokan siswa menjadi tiga kelompok gaya belajar yang dibuat berdasarkan teori De Poter \& Hernacki tentang indikator gaya belajar berdasarkan kajian teori, pernyataann angket disesuaikan berdasarkan tiga kategori gaya belajar yaitu gaya belajar visual, gaya belajar auditori dan gaya belajar kinestetik yang terdiri dari 24 pernyataan.

Wawancara di sini bertujuan untuk menggali informasi lebih lanjut tentang gaya belajar siswa, memperkuat jawaban siswa dan mengindari kesalahan pada penelitian, serta untuk mengetahui hal-hal dari siswa sebagai responden secara lebih mendalam.

Hasil observasi terhadap gaya belajar siswa, hasil tes kemampuan representasi matematis, dan angket gaya belajar diakukan analisis data kuantitatif. analisis data kualitatif dilakukan terhadap hasil wawancara siswa.

\section{HASIL DAN PEMBAHASAN}

Berdasarkan hasil perolehan observasi gaya belajar siswa yang dilakukan selama tiga pertemuan dan angket gaya belajar diperoleh. 
Tabel 1. Hasil Observasi dan Angket Gaya Belajar

\begin{tabular}{clcc}
\hline No & Jenis Gaya Belajar & $\begin{array}{c}\text { Jumlah Siswa Hasil } \\
\text { Observasi }\end{array}$ & $\begin{array}{c}\text { Jumlah Siswa Hasil } \\
\text { Angket }\end{array}$ \\
\hline 1 & Visual & 7 & 7 \\
2 & Auditorial & 9 & 8 \\
3 & Kinestetik & 7 & 9 \\
4 & Visual-Auditorial & 2 & 2 \\
5 & Auditorial-Kinestetik & 1 & 1 \\
6 & Visual-Kinestetik & 3 & 2 \\
\hline
\end{tabular}

Dari hasil observasi dan hasil angket gaya belajar diperoleh 2 siswa yang hasil gaya belajar pada observasi berbeda dengan hasil gaya belajar pada angket, dari perbedaan hasil tersebut, maka untuk mengetahui 2 siswa tersebut tergolong ke dalam gaya belajar visual, auditorial, dan kinestetik maka digunakan rata-rata persentase dari masing-masing gaya belajar sehingga disimpulkan bahwa S8 memiliki gaya belajar kinestetik karena hasil rata-rata dari ketiga gaya belajar, gaya belajar kinestetik yang tertinggi dari gaya belajar yang lainnya yaitu 70,0\%. S23 memiliki gaya belajar Kinestetik karena dari ketiga gaya belajar, nilai ratarata gaya belajar kinestetik tertinggi yaitu $68,33 \%$.

Tabel 2. Kriteria Hasil Perolehan Skor Tes Kemampuan Representasi Matematis Setiap Gaya Belajar Siswa

\begin{tabular}{ccccccc}
\hline $\begin{array}{c}\text { Gaya } \\
\text { Belajar }\end{array}$ & $\begin{array}{c}\% \\
\text { Representasi } \\
\text { Visual }\end{array}$ & Kriteria & $\begin{array}{c}\% \\
\text { Representasi } \\
\text { Simbolik }\end{array}$ & Kriteria & $\begin{array}{c}\% \\
\text { Representasi } \\
\text { Verbal }\end{array}$ & Kriteria \\
\hline Visual & 96,4 & $\begin{array}{c}\text { Sangat } \\
\text { Baik }\end{array}$ & 64,29 & Cukup & 39,29 & $\begin{array}{c}\text { Kurang } \\
\text { Sekali }\end{array}$ \\
Auditori & 96,88 & $\begin{array}{c}\text { Sangat } \\
\text { Baik }\end{array}$ & 75 & Cukup & 25 & $\begin{array}{c}\text { Kurang } \\
\text { Sekali }\end{array}$ \\
Kinestetik & 100 & $\begin{array}{c}\text { Sangat } \\
\text { Baik }\end{array}$ & 69,44 & Cukup & 36,11 & $\begin{array}{c}\text { Kurang } \\
\text { Sekali }\end{array}$ \\
\hline
\end{tabular}

Berdasarkan Tabel 2 kriteria hasil perolehan soal tes representasi matematis setiap gaya belajar siswa, diperoleh kemampuan representasi visual tidak memiliki perbedaan yang jauh untuk setiap kelompok gaya belajar, pada kemampuan representasi visual setiap kelompok gaya belajar memiliki kriteria yang sama yaitu sangat baik. Pada kemampuan representasi simbolik setiap kelompok gaya belajar memiliki kriteria yang sama yaitu cukup. Pada kemampuan representasi verbal juga tidak memiliki perbedaan untuk setiap kelompok gaya belajar, kemampuan representasi verbal setiap kelompok gaya belajar memiliki kriteria yang sama yaitu kurang sekali.

Tabel 3. Kriteria Keseluruhan Hasil Perolehan Skor Tes Kemampuan Representasi Matematis Setiap Gaya Belajar Siswa

\begin{tabular}{ccc}
\hline Gaya Belajar & Persentase & Kategori \\
\hline Visual & 71,43 & Cukup \\
Auditorial & 71,25 & Cukup \\
Kinestetik & 73,89 & Cukup \\
\hline
\end{tabular}


Berdasarkan hasil Tabel 3 yaitu kriteria keseluruhan hasil perolehan skor tes representasi matematis berdasarkan gaya belajar siswa diperoleh setiap kelompok gaya belajar memiliki kemampuan representasi matematis yang sama yaitu kriteria cukup. Pada kelompok siswa yang dengan kategori gaya belajar kinestetik memiliki persentase yang paling tinggi dibandingkan kelompok gaya belajar yang lainnya yaitu gaya belajarvisula dan gaya belajar auditorial.

Berdasarkan hasil tes representasi matematis, observasi gaya belajar, angket gaya belajar, wawancara dan analisis dari hasil penelitian, dapat diketahui bahwa kemampuan representasi matematis tiap kelompok gaya belajar siswa memiliki kriteria yang sama yaitu berada pada kriteria cukup. Hal tersebut menunjukkan bahwa kemampuan representasi matematis siswa pada materi trigonometri tidak dipengaruh oleh gaya belajar siswa. Selain itu, kecendrungan kemampuan representasi matematis berdasarkan gaya belajar siswa juga dapat diketahui. Hal tersebut sesuai dengan pernyataan De Porter dan Hernacki (2015: 111) yaitu kemampuan menyerap informasi setiap siswa cenderung berbeda berdasarkan modalitas belajarnya.

\section{Kemampuan Representasi Matematis Siswa yang Memiliki Gaya Belajar Visual}

Berdasarkan Tabel 3 terlihat bahwa hasil rata-rata kemampuan representasi siswa yang memiliki gaya belajar visual dalam menyelesaikan lima butir soal kemampuan representasi pada materi trigonometri adalah $71,43 \%$ dengan kategori cukup.

Berdasarkan Tabel 2 rata-rata kemampuan representasi visual siswa adalah $96,43 \%$ dengan kategori sangat baik. Dari 7 orang siswa yang memiliki gaya belajar ini pada jenis soal kemampun representasi visual tidak ada seorangpun berada pada kategori tidak mampu, kategori kurang mampu hanya 1 orang dan 6 orang siswa berada pada kategori mampu. Rata-rata kemampuan simbolik atau ekspresi matematis siswa yang memiliki gaya belajar visual adalah 64,29\% dengan kategori cukup, di mana 3 orang siswa berada pada kategori tidak mampu, dan 4 orang siswa kategori kurang mampu. Selain itu, rata-rata kemampuan representasi kata-kata atau teks tertulis siswa yang memiliki gaya belajar visual adalah 39,29\% dengan kategori kurang sekali. Dari 7 orang siswa yang memiliki gaya ini diantaranya 5 orang ada pada kategori kategori kurang mampu, 2 orang siswa berada pada kategori mampu.

\section{Kemampuan Representasi Matematis Siswa yang Memiliki Gaya Belajar Auditorial}

Berdasarkan Tabel 3 hasil rata-rata kemampuan representasi siswa yang memiliki gaya belajar auditorial dalam menyelesaikan lima butir soal kemampuan representasi pada materi trigonometri adalah $71,25 \%$ dengan kategori cukup.

Berdasarkan Tabel 2 rata-rata kemampuan representasi visual yang memiliki gaya belajar auditorial adalah 96,88\% dengan kategori sangat baik. Dari 8 orang siswa yang memiliki gaya belajar ini tidak ada seorangpun yang berada pada kategori tidak mampu, siswa yang kurang mampu ada 1 orang dan 7 orang siswa berada pada kategori mampu. Rata-rata kemampuan simbolik atau ekspresi matematis siswa yang memiliki gaya belajar auditorial adalah $75 \%$ dengan 
kategori cukup, dari 8 orang, 1 orang dengan kategori tidak mampu, dan 6 orang pad akategori kurang mampu, 1 orang siswa berada pada kategori mampu. Selanjutnya, rata-rata kemampuan representasi kata-kata atau teks tertulis siswa yang memiliki gaya belajar auditorial adalah $25 \%$ dengan kategori kurang sekali, dari 8 orang siswa 7 orang berada pada kategori tidak mampu dan 1 orang siswa berada pada kategori mampu.

\section{Kemampuan Representasi Matematis Siswa yang Memiliki Gaya Belajar Kinestetik}

Berdasarkan Tabel 2 rata-rata kemampuan representasi siswa yang memiliki gaya belajar kinestetik dalam menyelesaikan lima butir soal kemampuan representasi pada materi trigonometri adalah 73,89\% dengan kategori cukup.

Berdasarkan Tabel 2 rata-rata kemampuan representasi visual siswa yang memiliki gaya belajar ini semuanya ada pada kategori sangat baik. Dari 9 orang siswa yang memiliki gaya belajar kinestetik tidak ada seorangpun yang berada pada kategori tidak mampu, tetapi 9 orang siswa tersebut berada pada kategori mampu atau memperoleh skor 4. Rata-rata kemampuan ekspresi matematis yang memiliki gaya belajar kinestetik adalah 69,44\% dengan kategori cukup, 2 orang siswa berada pada kategori tidak mampu dan 7 orang adan pada kategori kurang mampu. Rata-rata persentase kemampuan representasi kata-kata atau teks tertulis yang memiliki gaya belajar ini 36,11\% dengan kategori kurang sekali, 7 orang siswa berada pada kategori tidak mampu dan 2 orang siswa berada pada kategori mampu.

\section{Gaya Belajar yang Memiliki Kemampuan Representasi Paling Baik Dalam Pembelajaran Matematika.}

Hasil dari kemempuan representasi ditemukan adanya keberagaman yang dihasilkan, hasil tes tersebut menunjukan bahwa siswa dengan gaya belajar kinestetik memperoleh hasil tes kemampuan representasi matematis yang lebih tinggi dibandingkan dengan hasil tes kemampuan representasi matematis siswa dengan gaya belajar yang lainnya. Hal ini disebabkan karena dari 29 orang siswa gaya belajar siswa yang dominan adalah siswa yang memiliki gaya belajar kinestetik sebanyak 9 orang siswa, setelah diberikan tes kemampuan representasi matematis dari 9 orang siswa yang memiliki gaya belajar kinestetik keseluruhan siswa mampu untuk membuat melukiskan diagram, gambar secara lengkap, benar dan sistematisdan 2 orang siswa mampu memberikan penjelasan secara matematis masuk akal dan jelas serta tersusun secara logis dan sistematis.

Sejalan dengan Komala \& Suryadi (2018), keberagaman jawaban siswa yang ditemukan dari hasil kemampuan representasi dipengaruhi oleh kemampuan awal matematikanya dan merupakan wujud dari strategi penyelesaian siswa dalam menyelesaikan soal tes kemamapuan representasi yakni kemamapuan visual, ekspresi matematik dan kata-kata yang diberikan berdasarkan kebiasaan berpikir masing-masing siswa. Selain itu pada kurikulum 2013 siswa dituntut untuk aktif dalam mengikuti pembelajaran sedangkan siswa yang memiliki gaya belajar kinestetik hampir keseluruhan aktif dalam pembelajaran matematika sehingga mampu menjalankan pembelajaran matematika dengan baik dan mampu merepresentasikan dalam memecahkan masalah. 


\section{KESIMPULAN}

Berdasarkan hasil penelitian dan pembahasan: (1) Kemampuan representasi matematis siswa yang memiliki gaya belajar visual berada pada kategori cukup atau $71,43 \%$ di mana jenis representasi visual berada pada kategori sangat baik, jenis representasi persamaan dan ekspresi matematik berada pada kategori cukup, dan kata-kata atau teks tertulis berada pada kategori kurang sekali; (2) Kemampuan representasi matematis siswa yang memiliki gaya belajar auditorial berada pada kategori cukup atau $71,25 \%$ di mana jenis representasi visual berada pada kategori sangat baik, jenis representasi persamaan dan ekspresi matematik berada pada kategori cukup, dan kata-kata atau teks tertulis berada pada kategori kurang sekali; (3) Kemampuan representasi matematis siswa yang memiliki gaya belajar kinestetik berada pada kategori cukup atau 73,89\% di mana jenis representasi visual berada pada kategori sangat baik, jenis representasi persamaan dan ekspresi matematik berada pada kategori cukup, dan kata-kata atau teks tertulis berada pada kategori kurang sekali; (4) Gaya belajar kinestetik memiliki kemampuan representasi paling baik dalam pembelajaran matematika berada pada kategori cukup atau $73,89 \%$, di mana siswa dengan gaya belajar kinestetik memperoleh hasil tes kemampuan representasi matematis yang lebih tinggi dibandingkan dengan hasil tes kemampuan representasi matematis siswa dengan gaya belajar yang lainnya.

\section{REFERENSI}

Cai, J., Lane, S., \& Jakabcsin, M. S. (1996). The role of open-ended tasks and holistic scoring rubrics: Assessing students' mathematical reasoning and communication. Communication in mathematics, $K-12$ and beyond, 137-145. Reston, VA: The National Council of Teacher of Mathematics.

De Porter, B \& Hernacki, M. (2015). Quantum Learning. Bandung: Kaifa.

Gallenstein, N. L. (2005). Engaging young children in science and mathematics. Journal of Elementary Science Education, 17(2), 27-41. https://doi.org/ 10.1007/BF03174679.

Komala, E., \& Suryadi, D. (2018). Analysis of internal and external mathematical representation ability to senior high school students in Indonesia. JPhCS, 1132(1), 012047. doi:10.1088/1742-6596/1132/1/012047.

Komala, E,. Suryadi, D., \& Dasari, D. (2020). Learning Obstacle Related to the Ability of High School Student Representation to the Trigonometry Concept. In International Proceedings Conferences Series, 43-49. https://doi.org/10.22 236/ie.v1i1.107

NCTM. (2000). Principlles and Standars for School Mathemathic. Reton VA: National Teachers of Council of Mathemathics Inc.

Nurhayati, E., \& Subekti, F. E. (2017). Deskripsi Kemampuan Penalaran Matematis Siswa Ditinjau dari Gaya Belajar dan Gender. AlphaMath: Journal of Mathematics Education, 3(1), 66-78.

Sabirin, M. (2014). Representasi dalam pembelajaran matematika. Jurnal Pendidikan Matematika, 1(2), 33-44. http://dx.doi.org/10.18592/jpm.v1i2.49 